\title{
Developing Writing Skills Through Reading
}

\author{
Bünyamin Celik ${ }^{1}$
}

\begin{abstract}
${ }^{1}$ Department of Languages, Tishk International University, Erbil, Iraq
Correspondence: Bünyamin Celik, Department of Languages, Tishk International University, Erbil, Iraq. Email: bunyamin.celik@ishik.edu.iq
\end{abstract}

Received: June 15, $2019 \quad$ Accepted: August 26, $2019 \quad$ Online Published: September 1, 2019

doi: 10.23918/ijsses.v6i1p206

\begin{abstract}
It is possible for the student to acquire basic language skills that will be used throughout his / her life, with the first teaching process of reading and writing planned correctly and effectively. Writing has always been a painful activity for learners. The fact that the duration of the course is limited and that other activities focused more take place in the language teaching puts this skill to the background. The excuse that the students are not well-equipped to do some writing activities can be counted as the reasons given by the related course teachers. Hence, second language learners constantly struggle to achieve language proficiency; therefore, they find it hard to produce written texts. However, reading materials will set a good model for which they can transfer into their own writing. The goal of this study is to put forward writing skills.
\end{abstract}

Keywords: Reading, Model, Structure, Language, Comprehension, Writing Skills

\section{Introduction}

The aim of today's foreign language teaching is to enable the learner to use the target language correctly and communicate effectively. In other words, the aim is to help the acquisition and development of comprehension and expression skills. In accomplishing this goal, the knowledge areas necessary for learning a foreign language can be developed efficiently through various teaching materials and activities used in the classroom. One of the instructional materials that can be used in this context is the literary genres that are thought to enrich the classroom environment with various features. These genres, which have been widely used in language teaching since the end of the twentieth century, are thought to contribute to the development of basic language skills. As a matter of fact, the fact that there is a close relationship between language and literary genres reveals that these types will contribute to the development of learner's language skills by reflecting various features and vocabulary of foreign language.

In addition, the use of literary genres as a teaching technique in the context of foreign language learning and teaching is also very useful for teaching knowledge topics such as vocabulary, grammar and pronunciation in addition to skill development. In addition to the contributions of literary genres, which are loaded with many functions in foreign language teaching, the fact that they reflect the social and functional aspects of language increases the importance of these teaching materials. While these genres present different aspects of language to the learner, they enable the learner to encounter the actual use of the language in different situations and environments, gain linguistic and cultural awareness, and they direct him to use the foreign language correctly. 
Literary genres, which are considered as useful teaching materials for demonstrating the culture and various features of a foreign language, provide the learner with information about vocabulary and vocabulary patterns that can be used in daily life while living in the society where the target language is spoken. In other words, the fact that some word patterns and metaphors used in daily life in literary genres take place in a real context provides the learner with knowledge of vocabulary and in what sense and in which structure this information will be used. As a matter of fact, this feature reveals the importance of literary genres as teaching materials that should be used in foreign language teaching. Therefore, it is an undeniable fact that these literary genres, which have a very important place in showing many features of the target language, will also contribute to the teaching of English as a foreign language.

On the other hand, writing skills, which is one of the four basic skills in foreign language teaching, is the most challenging skill for students and teachers. It is expected that two of the four basic skills, speaking and writing, will be used in order to see how much students can learn and to evaluate this process. Within these two skills, it is a known fact that the skill that students have difficulty is writing skills. Writing can be defined as being able to produce the symbols and signs necessary for the expression of thoughts in a motorized manner, putting structured information in the brain into written form, and expressing feelings and thoughts with a number of signs (Tangpermpoon, 2008; Jordan, 2003; Stubbs, 1980). According to Nunan (2003), writing is the way in which thoughts are revealed and expressed and presented to the reader in sentences and paragraphs. Nordin (2017), on the other hand, considers writing as a skill that can be improved by writing, and states that this is a process that involves research, reviewing and reorganizing thoughts on a piece of paper. In other words, how and where the expressions should be established, the order in which they should be placed and the parts that a meaningful whole should consist of are the main factors that need to be known for a good written expression (Hasan \& Akhand, 2010). In addition, writing has three dimensions: cognitive, affective and kinetic. The cognitive dimension is the mental process of interpretation of the acquired information, sensations and observations. The affective dimension is the simplicity, fluency, attractiveness, succinctness and readability of writing. Kinetic dimension is the coordination of muscle movements in using notebook, paper, pencil and writing (Köksal, 1999). Writing, which constitutes an important domain during both mother tongue and second or foreign language learning, requires skills rather than knowledge. These skills are acquired through practice. Like reading, writing has an important place in human life. Writing emotions, thoughts and imaginations clearly and comprehensively requires various mental skills. Through these skills, students learn to sort, limit and organize their thoughts, as well as determine the purpose of writing and apply rules.

However, during language acquisition, students regard writing as the most difficult skill. This may be due to the lack of clarity of the objectives and expectations of the teacher concerned or the curriculum prepared. One issue that most foreign language teachers are mistaken about the concept of writing is to expect students to write a complete essay individually without any help. However, when the foreign language teaching process is taken into consideration, it cannot be observed. In fact, the process is the same in teaching mother tongue. Depending on the level of the student, activities such as writing a sentence, a paragraph, a list or note-taking can also be considered as a writing activity in the process followed. (Storch, 2005). Therefore, it is known that activities to gain writing skills have many benefits in language learning and teaching process. 
As stated in Akpinar's (2007) study, writing skills are very important in terms of revealing the weak points of the students and guiding them on this issue. In general, it is possible to state that an effective writing lesson or any writing activity has many consequences for foreign language teachers to deal. In short, writing skills are thought to help achieve the following objectives:

- Reinforcing the structures or words taught,

- Creative thinking of students,

- Determining students' levels,

- Seeing the learning process more clearly,

- Teaching punctuation marks,

- Improving students' language skills,

- Better learning of other skills,

- Transforming students' competence into performance.

It is a fact revealed by many studies in the literature that the four main skills in language teaching complement each other and affect each other positively in the language acquisition process, contribute to development and increase student motivation over time (Ybarra \& Green, 2003; Oxford, 2001; Kasper, et al., 1999). In this context, especially the positive effectiveness of reading and reading habits on other skills was also determined in the studies conducted in the literature (Durukan, 2011 because people are constantly in the act of reading throughout life. Reading is a semantic activity with the mind, and through reading, information is perceived and transmitted to the brain by the sensation of the eye or touch and is made into meaning in the brain. The purpose of reading is to understand the message presented by the author in the text. In this respect, the reading action results in meaning-building. In reading, the reader achieves the meaning of the text by integrating the preliminary information and the information presented in the text. A text is not just written elements, but everything that has meaning associated with it. In some cases, non-written visual elements, such as a picture, graphic, map, etc., can also be considered as text. According to Dechant (2013), reading is the process of interpreting a written text. This interpretation requires two things: recognition and perception. Recognition is the recognition of letters and words and is a sensory activity. The recognition activity is followed by the perception of the material in the brain. During perception, this material is both organized, attached meaning, and linked to previous knowledge (Ybarra, \& Green, 2003). Accordingly, reading can be defined as the process of extracting meaning constructing his own from texts as a result of mental processing of the symbols taken through sensory organs. During reading, the individual makes a connection between his / her prior knowledge and the information presented in the text. The individual combines his / her prior knowledge with the information presented in the text and reaches a new idea (Celik, 2018). Therefore, reading has a significant role in language development. Bright and McGregor state that reading contributes to language learning to a large extent, and they conclude that "where there is little reading there will be little language learning. ... the student who wants to learn English will have to read himself into a knowledge of it unless he can move into an English environment" (1970, p.52). Reading holds an important place in foreign language learning process because it will allow students to have a good command of it. Krashen also emphasizes the role of reading in foreign language learning process as "reading exposure is the primary means of developing language skills" (1989, p.109). One of the many advantages of reading is writing skills improvement (Day \& Bamford, 1998; Krashen, 1993). Similarly, Dubin and Olshtain (1977) are of the opinion that reading has a positive effect on writing. Though writing has always been a challenge for students, good writing 
skills will allow conveying messages with ease and clarity. Krashen states the benefits of good writing skills as "Writing is, however, a powerful intellectual tool for cognitive development - it can make you smarter. ...Writing enables us to explore and change the worlds of ideas and experiences the brain creates" (Krashen, 1987, p.116, adapted from Escribano, 1999).

Developing writing skills through reading is an effective strategy in foreign language learning. Both reading and writing are meaningful interaction with texts (Tsai, 2006). Tierney and Pearson (1983) mention this interaction as "at the heart of understanding the reading/writing connection, one must begin to view reading and writing as essentially similar processes of meaning construction" (p. 568). Writing and reading are similar in that they both require students to learn language patterns and construct meaning.

Hedge (2003) argues that written texts will raise awareness of students about language structure. Without vocabulary and grammar, knowledge comprehension of a reading material fails. As comprehension does not occur, students will not be able to develop their language competence, which will prevent them from producing a good written text. Reading is simply the interpretation of a written message (Mart, 2012). Therefore, the more students gain a better understanding of reading materials, the better ability they will show to generate written texts.

\section{Developing Writing Skills through Reading}

Demonstrating writing proficiency relies on language proficiency in that language. Without language proficiency students cannot achieve in foreign language learning. Reading is a useful learning tool that can close this gap. Written texts are useful language input sources. Reading, as being one of the four basic skills, is an activity that requires understanding. "Reading is the activity of seeing, perceiving, comprehending and making sense of all words, sentences or writing with all its elements (Durmuş, 2013). In other words, "Reading is the activity of deriving meaning from written symbols through the collaboration of cognitive behaviors and psychomotor skills" (Demirel, 2016). This activity is carried out with the coordination of mind and eye and the meaning of written expressions. Reading is one of the most important sources of information (Fletcher \& Portalupi, 2001). One of the important objectives of reading is to enable the foreign learner to understand and interpret the written text in the target language correctly (Güzel \& Barın, 2013). Text, meaningful structures consisting of consecutive sentences, words and visuals. All kinds of information, feelings and thoughts are placed in this structure in a logical order (Gargiulo, 2007). According to Elhabiri (2012), the definition of the text is made in different ways according to daily and scientific language. It is a written whole consisting of multiple sentences as it is understood from the word "text" in everyday language. Within the framework of linguistics, not only written words but also oral words are called text.

It is clear that oral skills development, which is one of the requirements of the communicative approach, is important for the learners, as well as the ability to express oneself in writing and to translate thoughts into writing in the target language (Mart, 2018). Berninger and Winn (2006) argue that "Writing is the process of transcribing structured information in the brain into symbols". It is thought that writing has an important role in providing cognitive development. In this context, writing activity is a process that involves obtaining and expressing information. Writing, which is one of the most powerful communication expressions of the learner, is also a key for the success of the learner. In order to achieve this aim, the teacher, who uses the story as a teaching material, must activate the learners' previous knowledge during 
the reading process, arrange the students' thoughts and help them prepare a draft, teach the learner the process of writing by reviewing and evaluating the drafts and ensure the continuity of this chain of action. If these skills are acquired, the habit of writing in the target language can also be established in the learner.

In foreign language teaching, writing skill, which is seen as the last stage of language skills and thought to be the most difficult skill, requires the use of foreign language in writing correctly and in accordance with the rules (Demirel, 2016). This skill can only be improved by practice. It is thought that reading, which is thought to be combined with writing in practice, will improve the writing skill by providing development of thinking. As Öz (2011) states, "writing skills are directly related to reading skills." It is aimed that learners in foreign language teaching actively use the information they have gained in the classroom with writing activities and express their thoughts in a foreign language in writing (Güzel \& Barın, 2013). These goals can be achieved through various writing activities.

In the classroom environment where foreign language teaching is carried out, reading and writing skills in that language can only develop as long as the practices and exercises that attract the attention of the students are performed. In this context, reading skills can be improved by reading practice, and writing skills can be improved by writing practice. These practices include some activities that should be done before, during and after the main activity. Story as being one of the literary genres written in the target language for the development of reading skills is also very appropriate to use the story and similar resources can be used because it is short and more appropriate for classroom environment.

When reading is done, students will acquire language input. Reading will help learners to learn from what others have written (Hudson, 2007). Well-written reading materials will set a model to see structure and vocabulary use (Hudson, 2007), and learners will transfer the text structures they have learnt into their own writing. Reading will enable learners to internalize how vocabulary and structures function in the text. "Students are also exposed to language patterns that help them to see the many and complex ways that sentences and paragraphs can be put together" (Vandrick, 2003, p.265). Apparently, a good command of grammatical structures will help students build on writing skills.

Both reading and writing activities are involved in written text. Kennedy \& Bolitho (1985, p.85) explain the role of text for reading and writing activities as:

The actual content of the written text may be the same but the difference is that reading is concerned with the recognition of aspects of that structure, whereas writing has to do with the production of the text. In this respect reading may be regarded as a necessary precondition for any writing task, since the writer must be aware of the structure of a particular type of writing before he can produce it.

The relationship between reading and writing has been well recognized, in that "good reading, like effective writing, involves generative processes that create meaning by building relations between the text and what we know, believe, and experience" (Wittrock, 1983). Writing has been considered a generative activity (Hudson, 2007). Writing requires using words accurately in a text. These words must create a meaning. And a good writing occurs when these words and what students know are linked together. Grammar patterns set the foundations of good writing. Simply put, writing is demonstrating what students know in a meaningful text. 
Reading requires comprehension, through generating meaning of a text. Both skills involve generating relations among words, sentences, and paragraphs (Hudson, 2007). Comprehending will lead to composing which is constructing meaning, developing and expressing ideas (Sqire, 1983). Comprehension of reading materials will help students master the language patterns. Consequently, students can develop their ideas in a text.

Reading will inspire learners, in that it develops independent thinking. Those who read abundantly, will have the ability to judge ideas and opinions in the texts. Writing requires organizing these ideas and opinions into a text. Abundant reading will also give students an idea to compare their own work with well-written texts. What is more, reading will enhance cultural knowledge of students, and thus, reading will play a stimulating role to change writing from an annoying activity into an enjoyable learning experience. Students will gather ideas and knowledge through reading that will support their writing performance.

\section{Conclusion}

The ability to write correctly in a foreign language is becoming increasingly important in the global community. Therefore, training writing plays an increasingly important role in both the second and foreign languages (Weigle, 2012). Writing is a narrative skill. Writing is one of the most difficult skills that require the mastery of various linguistic, cognitive and sociocultural abilities that second language learners are expected to acquire (Barkaoui, 2007).

This skill, which is described as difficult, requires the learner to express his / her thoughts in writing. The learner describes himself in writing with words. Writing, which is a concrete indicator of language, is a skill that can be developed gradually. These steps include development, planning, drafting and reviewing (Kavaliauskiene \& Kaminskiene, 2009). Writing skill, including progressive skill development, is a language skill that develops over time. As a matter of fact, Ferris (2003) states that scientists have been focusing for a long time on the idea that writing is a process rather than a product of writing. Similarly, Hyland \& Hyland, (2019) states that writing is a developmental process.

Generally speaking, the aim of today's foreign language teaching is to enable the learners to acquire highlevel language skills such as creative and critical thinking, communication, using the target language correctly, including skills such as understanding, interpreting and explaining what they read in the target language. In this context, basic language skills are discussed in four groups as reading, writing, speaking and listening. Foreign language teaching is also a combination of these skills in an interactive way. Reading and writing skills are internal activities that do not require mutual communication. It is stated that these two skills are interdependent, complementary and contribute to the development of each other. As Kuta (2008) points out, reading and writing are interdependent processes that improve each other reciprocally. If one process is neglected, the other is damaged. Especially reading activities contribute to the development of writing skills by providing input for writing activities while contributing to the development of reading skills at the same time. On the basis of particular emphasis on writing in the classroom environment where foreign language teaching is carried out is to help learners to learn the target language systems, to contribute to their achievement of language competence, to develop self-expression skills and to contribute to their intellectual development in the target language (Hedge, 2001). The development of writing skills is linked to the development of reading skills. Therefore, while designing 
classroom activities in foreign language teaching, reading and writing activities can be combined to enable learners to develop both skills. Reading and writing are skills that can be taught together. "There is a clear link between reading and writing: they are both interdependent and mutual processes as personal and social activities" (Kavaliauskiene \& Kaminskiene, 2009). When the activities are prepared considering this relationship between reading and writing, it can be ensured that learners perform better in both reading and writing in terms of tasks given in the classroom environment. Grammar and vocabulary have an important role to play in improving writing skills as well as reading skills. The more the learner is exposed to reading, the more he develops his writing skills, because reading will increase their vocabulary and they will become more familiar with grammar and discourse structures. As a matter of fact, the vocabulary knowledge and writing performance of the learners are significantly interrelated. In addition, when various reading activities are performed before the writing activities are carried out, it will also contribute to the development of writing skills by enabling the learners to associate the events in the story, people with their own lives, grammatical structures and the words they already know and learn.

Writing, which requires skills rather than knowledge, is a process that is related to the development of cognitive skills and can be made more efficient through activities such as story reading, comprehension and inference. Indeed, a successful writing is achieved through plenty of reading. In order to achieve in writing, learners need to write more in addition to reading. While teaching a foreign language, it should be aimed to give the learners skills in writing activities in accordance with the rules of the target language and to develop aesthetic understanding by presenting literary genres to them. High level of writing fluency should be possessed for language proficiency. Good writing skills stem from language competence and thinking ability. Reading will allow students to learn language patterns and furthermore, reading will develop their comprehension skills. Reading which contributes to language learning is a useful source of developing writing skills.

\section{References}

Akpinar, F. (2007). The effect of process-oriented writing instruction on writer's block, writing apprehension, attitudes towards writing instruction and writing performance. Unpublished PhD thesis. Istanbul Technical University, College of Foreign Languages.

Barkaoui, K. (2007). Teaching writing to second language learners: Insights from theory and research. TESL Reporter, 40(1), 35-48.

Berninger, V. W., \& Winn, W. (2006). Implications of advancements in brain research and technology for writing development, writing instruction, and educational evolution. Handbook of writing research, 96-114.

Bright, J. A., \& McGregor, G. P. (1970). Teaching English as a second language: Theory and techniques for the secondary stage. Addison-Wesley Longman Ltd.

Celik, B. (2018). Improvement of Reading Skills in the Second Foreign Language Courses by the "AntiMethod" Way. International Journal of English Linguistics, 8 (4), 237-252. https://doi.org/10.5539/ijel.v8n4p237

Day, R. R., Bamford, J., Renandya, W. A., Jacobs, G. M., \& Yu, V. W. S. (1998). Extensive reading in the second language classroom. RELC Journal, 29(2), 187-191.

Dechant, E. (2013). Understanding and teaching reading: An interactive model. Routledge.

Demirel, Ö. (2016). Yabancı dil ögretimi, Ankara: Pegem Akademi Yayıncılık.

Durmuş, M. (2013). Yabancılara Türkçe ögrretimi. Ankara: Grafik Yayınları.

Durukan, E. (2011). Effects of cooperative integrated reading and composition (CIRC) technique on reading-writing skills. Educational Research and Reviews, 6(1), 102-109. 
International Journal of Social Sciences \& Educational Studies ISSN 2520-0968 (Online), ISSN 2409-1294 (Print), September 2019, Vol.6, No.1

Elhabiri, H. (2012-2013). Teaching the Writing Skills through Literary Texts Case of 2nd Year EFL Students at Djilali Liabes University (Doctoral dissertation). Englewood, CO: Libraries Unlimited.

Escribano, P. D. (1999). Teaching writing through reading: a text-centred approach. Ibérica, Revista de la Asociación Europea de Lenguas para Fines Específicos, (1), 55-62.

Ferris, D. R. (2003). Response to student writing: Implications for second language students. Routledge.

Fletcher, R., \& Portalupi, J. (2001). Writing workshop. Portsmouth, NH: Heinemann.

Gargiulo, T. L. (2007). Once upon a time: Using story-based activities to develop breakthrough communication skills. John Wiley \& Sons.

Güzel, A. ve Barın, E. (2013). Yabancı dil olarak Türkçe öğretimi, Ankara: Akçağ

Hasan, M. K., \& Akhand, M. M. (2010). Approaches to writing in EFL/ESL context: Balancing product and process in writing class at tertiary level. Journal of NELTA, 15(1-2), 77-88.

Hedge, T. (2001). Teaching and learning in the language classroom (Vol. 106). Oxford, England: Oxford university press

Hedge, T. (2003). Teaching \& learning in the language Classroom. UK: OUP.

Hudson, T. (2007). Teaching Second Language Reading. Oxford: Oxford University Press.

Hyland, K., \& Hyland, F. (Eds.). (2019). Feedback in second language writing: Contexts and issues. Cambridge university press.

Jordan, R. R. (2003). Academic Writing Course-Study Skill in English, Pearson Education, 2003: Academic Writing Course-Study Skill in English (Vol. 1). Bukupedia.

Kasper, L. F., Babbitt, M., Mlynarczyk, R. W., Brinton, D. M., \& Rosenthal, J. W. (1999). Contentbased college ESL instruction. Routledge.

Kavaliauskienè, G. (2009). Proficiency in reading, writing and translation skills: ESP aspect. Vertimo Studijos, 2(2), 171-184. https://doi:10.15388/VertStud.2009.10611

Kennedy, C. \& R. Bolitho (1985). English for Specific Purposes. Hong Kong: Macmillan.

Köksal, K. (1999). Okuma Yazmanın Öğretimi. Ankara: Pegem Akademi Yayıncılık.

Krashen, S. (1989). Language Acquisition and Language Education. Prentice Hall International.

Krashen, S. (1993). The Power of Reading: Insights from the Research.

Kuta, K. W. (2008). Reading and Writing to Learn. London: Greenwood Publishing.

Mart, C. T. (2012). Developing Speaking Skills through Reading. International Journal of English Linguistics, 2(6), 91-96

Mart, C.T. (2018). From communicative competence to language development. International Journal of English Linguistics, 8 (2), 163-167.

Nordin, S. M. (2017). The best of two approaches: Process/genre-based approach to teaching writing. The English Teacher, 11.

Nunan, D. (2003). Practical English. Language Teaching. New York: Mc Graw Hill.

Oxford, R. (2001). Integrated Skills in the ESL/EFL Classroom. ERIC Digest.

Öz, F. (2011). Uygulamalı Türkçe öğretimi. Ankara: Anı Yayıncılık.

Squire, J.R. (1983). Composing and Comprehending: Two Sides of the Same Basic Process. Language Arts, 60(5), 581-589

Storch, N. (2005). Collaborative writing: Product, process, and students' reflections. Journal of Second Language Writing, 14(3), 153-173. https://doi.org/10.1016/j.jslw.2005.05.002

Stubbs, M. (1980). Language and literacy: The sociolinguistics of reading and writing. Routledge \& Kegan Paul, 9 Park St., Boston, MA 02108.

Tangpermpoon, T. (2008). Integrated approaches to improve students writing skills for English major students. ABAC Journal, 28(2).

Tierney, R. J., \& Pearson, P. D. (1983). Toward a composing model of reading. Language Arts, 60, 568580.

Tsai, J. (2006). Connecting Reading and Writing in College EFL Courses. The Internet TESL Journal, 12(12). Retrieved from http://iteslj.org/Articles/Tsai-ReadingWritingConnection.html 
Vandrick, S. (2003). Literature in the teaching of second language composition. In Kroll, B. ed. Exploring the dynamics of second language writing. Cambridge: Cambridge University Press

Weigle, S. C. (2012). Assessment of writing. The encyclopedia of applied linguistics. https://doi.org/10.1002/9781405198431.wbeal0056

Wittrock, M.C. (1983). Writing and the Teaching of Reading. Language Arts, 60(5), 600-60

Ybarra, R., \& Green, T. (2003). Using technology to help ESL/EFL students develop language skills. The Internet TESL Journal, 9(3), 1-5. 